\title{
An Evaluation Of RFID Door Security System At Taipei Arena Ice Land Based On Technology Acceptance Model
}

Kuei-Mei Cheng, National Taiwan University of Physical Education \& Sport, Taiwan R.O.C.

\begin{abstract}
This study is based on technology acceptance model (TAM). It investigates consumer attitudes toward the use of and consumer behavioral intention to use an RFID door security system at Taipei Arena Ice Land. This study adopts a questionnaire method using purposive sampling and collects data from 250 consumers of Taipei Arena Ice Land. The results of this study show that: 1) system quality has a significant positive impact on perceived usefulness and perceived ease of use, 2) information quality has a significant positive impact on perceived usefulness and perceived ease of use, 3) service quality does not have a significant positive impact on perceived usefulness and perceived ease of use, 4) perceived ease of use has a significant positive impact on perceived usefulness, 5) perceived usefulness and perceived ease of use have a significant positive impact on attitudes toward use, 6) attitudes toward using have a significant positive impact on behavioral intentions to use, 7) perceived usefulness has a significant positive impact on behavioral intentions to use, and 8) perceived ease of use has a significant impact on attitude toward using via perceived usefulness.
\end{abstract}

Keywords: RFID Door Security System; Technology Acceptance Model; Taipei Arena Ice Land

\section{INTRODUCTION}

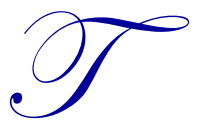

he earliest application of Radio Frequency Identification (RFID) was for military identification purposes during the Second World War in 1940. However, it was not until after Wal-Mart started to use it in 2005 that numerous industries around the world began to apply RFID to their businesses, from the logistics industry, hospitals, door security systems, retail supply chains, vehicle repairs, libraries, medical and healthcare industries, to restaurants and hotels hoping to promote performance. RFID is an automatic noncontact information signal identification technology and the biggest progress and innovation it represents is that, unlike the contact-based barcode system, it is capable of transmitting digital data through a wireless radio frequency and therefore does not require contact or a card reader for the exchange of data. Therefore, in recent years, RFID has generally been considered one of the most influential and important technological advancements for the future development of global business (Song, Tang, Wang, and Chen, 2009). There were seven stages in the development of RFID. The first stage was its inception and invention during the 1940s; the second stage was early experimentations and development in the 1950s; the third stage was the development of theoretical frameworks in the 1960s; the fourth stage was development and explorations during the 1970s; the fifth stage was commercial applications in the 1980s; the sixth stage involved standardization in the 1990s; and the seventh stage was in-depth applications from 2000 to the present (Oztaysi, Baysan, and Akpinar, 2009; Wang, 2007 \& 2008; Shen, 2008; Zhou, 2006; Chen, Shi, Cai, and Zhou, 2009). Following these seven stages, RFID has been widely applied to various areas, such as door security systems, cargo management systems, materials management systems, waste management system, medical system, transportation system, security system, veterinary surveillance system, automation control system, anti-counterfeiting management system, etc. (Wang, 2008; Yang, 2005; Liao, 2007).

The RFID system is mainly composed of three parts: 1) the Tag stores product information, 2) the Reader reads the information contained in the tag through wireless transmission and sends it out through the output interface 
of its application software, and 3) the Application retrieves and filters product information from the data received from the tag (Song, Tang, Wang and Chen, 2009). It is highly functional and stable. "Companies are much smarter than they were five years ago with RFID", says Patrick Connaughton, senior analyst for supply chain at Forrester Research (Cox, 2007). It is estimated that by 2014, healthcare industry, manufacture industry, and retail industry will show highest growth in RFID system application (Li, 2009). In the future, RFID applications are expected to change from large and expensive products to individual products with general applications, from closed systems to open systems and from item identification and logistics management to sensor networks. Technical or application problems, such as cost, signal interference, non-standardized prices, regulatory laws concerning electromagnetic radiation frequency, and issue of privacy, still remain to be solved (Zhang, 2011).

In the service industry nowadays, creating customer value remains an important issue. RFID is capable of creating potential customer value for companies and allowing them to respond to customer needs with new services. However, in the process of introducing RFID systems, the degree of service quality, system quality, and information quality will affect user satisfaction and their perceived ease of use in addition to perceived usefulness, which, in turn, influences their willingness to use RFID. Consequently, scholars have proposed theories related to user satisfaction and intention to use regarding technology products. In terms of the technology acceptance model (TAM), Davis, Bagozzi, and Warshaw (1989) were the first scholars to synthesize the theory of reasoned action and the theory of planned behavior proposed by Fishbein and Ajzen and modified them into a technology acceptance model based on the usage environment of information systems. They use this model to investigate and predict the degree of acceptance for information technology users and the key factors that influence user acceptance. TAM models how information technology users accept the technology and seeks to understand users' behavioral intention toward accepting new technology by analyzing the relationship among reasoned and affective perspectives and technology users. It also attempts to predict the users' degree of acceptance towards new technology in order to identify factors that influence the degree of acceptance. In TAM, perceived ease of use (PEOU) and perceived usefulness (PU) are two main factors that influence user decision (Chen, 2010). Perceived usefulness is defined as "the degree to which a person believes that using a particular system would enhance his or her job performance", and perceived ease of use is defined as "the degree to which a person believes that using a particular system would be free from effort." Therefore, in addition to being key factors that influence the technology users' degree of acceptance, perceived usefulness and perceived ease of use also affect user attitude toward using and intention to use. Beside TAM, information systems success model (ISSM) is also an important theory. Based on Mason's Information Influence Theory (IIT), DeLone and McLean (1992) synthesized previous empirical studies and proposed the information systems success model. The six dimensions of this model are system quality, information quality, service quality, usage, user satisfaction, and net benefits. Information quality measures the output quality of information systems system quality measures the desired characteristics of the information system; service quality measures the overall services delivered by the service provider; intention to use measures the degree to which a user is willing to continue using the system; user satisfaction measures user response after using the output information; and system usage benefits measure the positive or negative impact of the system on the customers or suppliers (Cai and Liang, 2009). DeLone and McLean (2003) point out that system quality, information quality, and service quality in ISSM will influence usage and user satisfaction and usage and user satisfaction will influence net benefits.

Since RFID is widely used in door security systems in many buildings, the relationship between RFID users' degree of acceptance and behavioral intention, in terms of these technology products and related system quality has become an important research topic. Taipei Arena Ice Land is the only skating rink in Taiwan that adheres international standards. It measures 61 meters in length and 30 meters in width, can accommodate 400 skaters, and has 800 seats. The arena also has an ice surface that meets the standard of the Winter Olympic Games. Its overall quality is approved by the International Skating Union (ISU) and Asian Skating Union (ASU). In addition to being a recreational facility for the general public, Taipei Arena Ice Land is also the main training ground for national teams and skaters of various disciplines. This arena has held numerous large-scale international ice sports competitions since its opening. Consequently, this study adopts TAM and uses system quality, information quality, and service quality in the ISSM as external variables to measure the quality of RFID systems. It aims to investigate the relationships between service quality, system quality, information quality, perceived ease of use, perceived usefulness, and consumers' attitude toward using, as well as their behavioral intention to using an RFID door security system at Taipei Arena Ice Land. It is hoped that the results of this study can provide suggestions for how to promote user satisfaction and intention to use RFID door security system applications. 


\section{METHODOLOGY}

\section{Research Object}

This study uses questionnaires and collects data through purposive sampling. The main research objects are consumers at Taipei Arena Ice Land. The questionnaire survey was conducted between 12 March 2012 and 18 March 2012, during which time the author and assistants personally went to Taipei Arena Ice Land to distribute survey questionnaires. A total of 260 questionnaires were sent out, all of which were returned (return rate is $100 \%$ ). After eliminating invalid questionnaires, there are 250 valid questionnaires (valid return rate is $96.1 \%$ ).

\section{Research Tool}

This study designed a questionnaire of "A Survey of Consumer Information Systems Success Model and Technology Acceptance Model" to collect data. There are three parts to the questionnaire. The first part surveys general individual information, including gender, age, education level, and frequency of usage. The second part measures ISSM scale, which is mainly based on "Scale of Willingness to Use Library Information System at Pintung University of Education" by Liu (2008). The three dimensions are system quality, information quality, and service quality, with a total of 22 questions. The third part measures TAM scale, which is mainly based on "Scale of Willingness to Use Digital Experience Area at National Taichung Library" by Lin (2011) and "Scale of Intention to Use Mobile Value-Added Services" by Lin (2007). The four dimensions are perceived usefulness, perceived ease of use, attitude toward using, and behavioral intention to use, with a total of 17 questions. The scale is measured using a 7-point Likert scale divided into strongly disagree, disagree, somewhat disagree, neutral, somewhat agree, agree, and strongly agree, measured from 1 to 7 , respectively.

\section{Research Structure}

The structure of this study is based on its research objectives and literature review. It is mainly based on TAM and ISSM as it investigates the relationships between the three external variables of system quality, information quality, and service quality, as well as perceived usefulness, perceived ease of use, attitude toward using, and behavioral intention. The structure is shown in Figure 1:

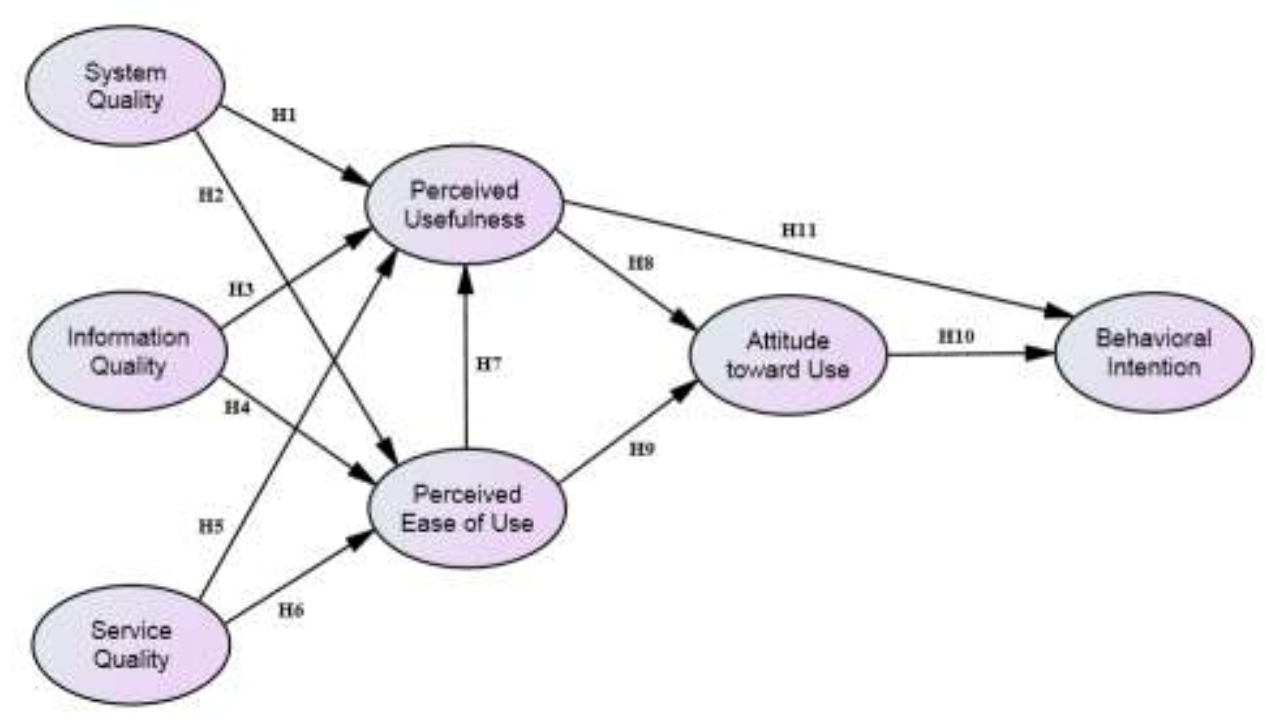

Figure 1: Research Structure 


\section{Research Hypotheses}

ISSM proposes that information quality affects user intention to use information technology (DeLone and McLean, 1992; DeLone and McLean, 2003; DeLone and McLean, 2004). Lin and Lu (2000) point out that information system quality includes dimensions, such as information quality, response time, and system impact, and believes that these three dimensions are capable of effectively predicting users' perceived usefulness and perceived ease of use. Cheong and Park (2005) also point out that perceived quality has a positive impact on users' perceived usefulness and perceived ease of use. On the other hand, research focusing on the behavior of online retail users has found that service quality has positive influence on perceived ease of use and perceived usefulness (Ahn, Ry and Han, 2007). Moreover, in their study of online consumer behavior, Saeed, Hwang and Yi (2003) point out that the higher degree perceived system quality, information quality and service quality are, the higher degree perceived usefulness will be. They also propose a synthesized structure and contend that system quality, information quality, and service quality will affect users' perceived ease of use. In addition, Davis' 1986 TAM theory proposes that an individual's intention to use information technology will be affected by perceived usefulness and perceived ease of use. In other words, the easier the information technology is perceived by the user, the more positive he or she will be in adopting the information technology system; also, perceived ease of use has a significant impact on perceived usefulness (Davis, 1986, 1989; Davis, Bagozzi and Warshaw, 1989). Xu (2005) believes that information quality, website response time, and internet self-efficiency all have a positive significant impact on perceived ease of use and perceived usefulness and therefore will affect ultimate attitude toward using and behavioral intention to use. Based on the research structure and related literature, this research proposes the following research hypotheses:

H1: System quality of RFID door security system has a significant positive impact on user's perceived usefulness.

H2: System quality of RFID door security system has a significant positive impact on user's perceived ease of use.

H3: Information quality of RFID door security system has a significant positive impact on user's perceived usefulness.

H4: Information quality of RFID door security system has a significant positive impact on user's perceived ease of use.

H5: Service quality of RFID door security system has a significant positive impact on user's perceived usefulness.

H6: Service quality of RFID door security system has a significant positive impact on user's perceived ease of use.

H7: User's perceived ease of use of RFID door security system has a significant positive impact on user's perceived usefulness.

H8: User's perceived usefulness of RFID door security system has a significant positive impact on user's attitude toward using.

H9: User's perceived ease of use of RFID door security system has a significant positive impact on user's attitude toward using.

H10: User's attitude toward using of RFID door security system has a significant positive impact on user's behavioral intention to use.

H11: User's perceived usefulness of RFID door security system has a significant positive impact on user's behavioral intention to use. 
H12: User's perceived ease of use of RFID door security system has a significant positive impact on user's attitude toward using through user's perceived usefulness.

\section{Data Analysis}

1. Descriptive statistical methods are used to understand the demographic variables and participation behavior for Taipei Arena Ice Land consumers.

2. A structural equation model is used to analyze the relationship between ISSM and TAM for Taipei Arena Ice Land consumers.

\section{RESEARCH RESULTS}

\section{Descriptive Statistics Of Sample Characteristics}

This study employs descriptive statistics to analyze the distribution of general participant data, as shown in Table 1. In the valid sample of 250 people, 107 are male (42.8\%) and 143 are female $(57.2 \%)$, indicating that females are the majority of consumers at Taipei Arena Ice Land. In terms of age, the largest group falls between 21 and 30 years old, which consists of 53.6\% of the valid samples; persons 20 years old (and under) is the second largest, consisting of $39.6 \%$ of the samples; and 41 years old (and above) is the smallest group, making up 2.0\% of the sample group. This indicates that the majority of consumers at Taipei Arena Ice Land are between 21 and 30 years old. In terms of education level, college students comprise the largest group, consisting of $65.6 \%$ of the samples; high school (and vocational school) is the second largest group, making up 12.4\% of the sample group; and the smallest group is junior high school (and under) students, consisting of $0.4 \%$ of the sample group. This indicates that the education level of the participants is mainly college. In terms of frequency of usage, "one time" makes up $77.6 \%$ of the samples and "two times" represents the smallest group, making up of $10.8 \%$ of the sample group.

Table 1: Descriptive Statistics of Sample Characteristics

\begin{tabular}{|c|c|c|c|c|}
\hline Background Variables & Category & Frequency & Percentage $(\%)$ & $\begin{array}{c}\text { Accumulated } \\
\text { Percentage (\%) }\end{array}$ \\
\hline \multirow[t]{2}{*}{ Gender } & Male & 107 & 42.8 & 42.8 \\
\hline & Female & 143 & 57.2 & 100 \\
\hline \multirow[t]{4}{*}{ Age } & 20 years old (and under) & 99 & 39.6 & 39.6 \\
\hline & 21 to 30 years old & 134 & 53.6 & 93.2 \\
\hline & 31 to 40 years old & 12 & 4.8 & 98 \\
\hline & 41 years old (and above) & 5 & 2 & 100 \\
\hline \multirow{3}{*}{$\begin{array}{l}\text { Weekly frequency of } \\
\text { usage }\end{array}$} & Once & 194 & 77.6 & 77.6 \\
\hline & Twice & 27 & 10.8 & 88.4 \\
\hline & Three times (and above) & 29 & 11.6 & 100 \\
\hline \multirow[t]{5}{*}{ Education level } & Junior high school & 3 & 1.2 & 1.2 \\
\hline & High school (or vocational school) & 31 & 12.4 & 13.6 \\
\hline & Junior college & 18 & 7.2 & 20.8 \\
\hline & College & 164 & 65.6 & 86.4 \\
\hline & Graduate school (and above) & 34 & 13.6 & 100 \\
\hline
\end{tabular}

\section{Data Analysis Using Structural Equation Model}

This study uses structural equation model to analyze the causal relationship between its research variables. It also conducts confirmatory factor analysis in order to eliminate non-fit variable parameters based on modification indices analysis (Li, 2006). Among the scales proposed in this study, the MI of SQ5, SQ6, SQ7, IQ4, SEQ1, SEQ2, SEQ6, SEQ8, ATT1, ATT5, B5, and B6 is too high, thus these items were deleted. The rest are retained. 


\section{Measurement Model Analysis}

\section{Assessing Convergent Validity}

This study conducts confirmatory factor analysis (CFA) on the scales of TAM and ISSM. The four dimensions of TAM are perceived usefulness, perceived ease of use, attitude toward using, and behavioral intention to use. The loadings all fall between 0.873 and 0.976 ; composite reliability falls between 0.946 and 0.969 ; and average variance extracted falls between 0.814 and 0.913 , as shown in Table 2.

Table 2: TAM Convergent Validity Analysis

\begin{tabular}{|c|c|c|c|c|c|c|c|c|c|}
\hline $\begin{array}{c}\text { Latent } \\
\text { Variables }\end{array}$ & $\begin{array}{c}\text { Observation } \\
\text { Variables }\end{array}$ & $\begin{array}{l}\text { Standardized } \\
\text { Regression } \\
\text { Weight }\end{array}$ & $\begin{array}{c}\text { Regression } \\
\text { Weight }\end{array}$ & S.E. & $\underset{\text { (t-value) }}{\text { C.R. }}$ & $\mathbf{P}$ & SMC & C.R. & AVE \\
\hline \multirow{3}{*}{$\begin{array}{l}\text { Perceived } \\
\text { Usefulness }\end{array}$} & PU1 & 0.976 & 1.000 & & & & 0.953 & 0.969 & 0.913 \\
\hline & PU2 & 0.972 & 0.957 & 0.021 & 45.786 & $* * *$ & 0.946 & & \\
\hline & PU3 & 0.918 & 0.901 & 0.028 & 31.711 & $* * *$ & 0.842 & & \\
\hline \multirow{3}{*}{$\begin{array}{l}\text { Perceived } \\
\text { Ease of Use }\end{array}$} & PEOU1 & 0.935 & 1.000 & & & & 0.874 & 0.959 & 0.887 \\
\hline & PEOU2 & 0.954 & 1.016 & 0.033 & 30.733 & $* * *$ & 0.910 & & \\
\hline & PEOU3 & 0.935 & 1.003 & 0.035 & 28.287 & $* * *$ & 0.875 & & \\
\hline \multirow{3}{*}{$\begin{array}{l}\text { Attitudes } \\
\text { towards } \\
\text { Usage }\end{array}$} & ATT2 & 0.916 & 1.000 & & & & 0.840 & 0.960 & 0.890 \\
\hline & ATT3 & 0.970 & 1.062 & 0.035 & 30.294 & $* * *$ & 0.940 & & \\
\hline & ATT4 & 0.943 & 1.059 & 0.039 & 27.271 & $* * *$ & 0.889 & & \\
\hline \multirow{4}{*}{$\begin{array}{l}\text { Behavioral } \\
\text { Intentions }\end{array}$} & BI1 & 0.913 & 1.000 & & & & 0.833 & 0.946 & 0.814 \\
\hline & BI2 & 0.919 & 1.024 & 0.042 & 24.110 & $* * *$ & 0.845 & & \\
\hline & BI3 & 0.904 & 0.982 & 0.043 & 22.989 & $* * *$ & 0.816 & & \\
\hline & BI4 & 0.873 & 0.974 & 0.046 & 21.229 & $* * *$ & 0.761 & & \\
\hline
\end{tabular}

The three dimensions of ISSM are system quality, information quality, and service quality. The loadings all fall between 0.873 and 0.943 ; composite reliability falls between 0.923 and 0.972 ; and average variance extracted falls between 0.752 and 0.853 (as shown in Table 3). The results indicate that dimensions of both TAM and ISSM possess convergence validity.

Table 3: ISSM Convergent Validity Analysis

\begin{tabular}{|c|c|c|c|c|c|c|c|c|c|}
\hline $\begin{array}{c}\text { Latent } \\
\text { Variables }\end{array}$ & $\begin{array}{c}\text { Observation } \\
\text { Variables }\end{array}$ & $\begin{array}{c}\text { Standardized } \\
\text { Regression } \\
\text { Weight }\end{array}$ & $\begin{array}{c}\text { Regression } \\
\text { Weight }\end{array}$ & S.E. & $\begin{array}{c}\text { C.R. } \\
\text { (t-value) }\end{array}$ & $\mathbf{P}$ & SMC & C.R. & AVE \\
\hline \multirow{4}{*}{$\begin{array}{l}\text { System } \\
\text { Quality }\end{array}$} & SQ1 & 0.920 & 1.000 & & & & 0.847 & 0.923 & 0.752 \\
\hline & SQ2 & 0.943 & 1.047 & 0.038 & 27.823 & $* * * *$ & 0.889 & & \\
\hline & SQ3 & 0.935 & 1.023 & 0.038 & 26.840 & $* * *$ & 0.874 & & \\
\hline & SQ4 & 0.927 & 1.061 & 0.041 & 26.057 & $* * *$ & 0.859 & & \\
\hline \multirow{6}{*}{$\begin{array}{l}\text { Information } \\
\text { Quality }\end{array}$} & IQ1 & 0.934 & 1.000 & & & $* * *$ & 0.872 & 0.972 & 0.853 \\
\hline & IQ2 & 0.933 & 0.950 & 0.033 & 28.534 & $* * *$ & 0.870 & & \\
\hline & IQ3 & 0.918 & 0.952 & 0.036 & 26.791 & $* * *$ & 0.842 & & \\
\hline & IQ5 & 0.922 & 0.986 & 0.036 & 27.199 & $* * *$ & 0.851 & & \\
\hline & IQ6 & 0.902 & 0.939 & 0.037 & 25.232 & & 0.814 & & \\
\hline & IQ7 & 0.932 & 0.981 & 0.035 & 28.341 & $* * *$ & 0.869 & & \\
\hline \multirow{3}{*}{$\begin{array}{l}\text { Service } \\
\text { Quality }\end{array}$} & SEQ3 & 0.873 & 1.000 & & & & 0.762 & 0.932 & 0.820 \\
\hline & SEQ4 & 0.927 & 1.116 & 0.052 & 21.481 & $* * *$ & 0.858 & & \\
\hline & SEQ5 & 0.916 & 1.106 & 0.053 & 20.970 & $* * *$ & 0.839 & & \\
\hline
\end{tabular}

\section{2. $\quad$ Assessing Discriminant Validity}

Discriminant validity examines whether two different dimension correlations are statistically different. This study adopts the confidence interval approach proposed by Torkzadeh, Koufteros and Pflughoeft (2003) in order to construct confidence intervals for the correlation coefficients between the dimensions. If the confidence interval for the correlation coefficient does not cover 1, then it can be inferred that there is complete correlation, and thus there is discriminant validity between the dimensions. The results for the discriminant validity for TAM and ISSM are 
shown in Tables 4 and 5. Since the 95\% confidence interval for the standardized correlation coefficient of the four dimensions of TAM and the three dimensions of ISSM do not cover 1, there is discriminant validity between these dimensions.

Table 4: Bootstrapping 95\% Confidence Interval for Correlation Coefficient of TAM

\begin{tabular}{|l|l|l|l|l|l|l|}
\hline \multirow{2}{*}{ Parameter } & \multirow{2}{*}{ Estimated } & \multicolumn{2}{|c|}{ Bias-corrected } & \multicolumn{2}{c|}{ Percentile Method } \\
\cline { 3 - 6 } & & Lower & Upper & Lower & Upper \\
\hline Perceived Usefulness<-->Perceived Ease of Use & 0.821 & 0.757 & 0.882 & 0.753 & 0.878 \\
\hline Perceived Usefulness<-->Attitudes towards Usage & 0.850 & 0.791 & 0.896 & 0.788 & 0.893 \\
\hline Perceived Usefulness<-->Behavioral Intention & 0.723 & 0.604 & 0.815 & 0.606 & 0.816 \\
\hline Perceived Ease of Use<--> Attitudes towards Usage & 0.834 & 0.774 & 0.882 & 0.773 & 0.882 \\
\hline Perceived Ease of Use<--> Behavioral Intention & 0.684 & 0.559 & 0.775 & 0.568 & 0.784 \\
\hline Attitudes towards Usage<-->Behavioral Intention & 0.731 & 0.605 & 0.833 & 0.608 & 0.839 \\
\hline
\end{tabular}

Table 5: Bootstrapping 95\% Confidence Interval for Correlation Coefficient of ISSM

\begin{tabular}{|l|l|l|l|l|l|}
\hline \multirow{2}{*}{ Parameter } & \multirow{2}{*}{ Estimated } & \multicolumn{3}{|c|}{ Bias-corrected } & \multicolumn{2}{c|}{ Percentile Method } \\
\cline { 3 - 7 } & & Lower & Upper & Lower & Upper \\
\hline System Quality<-->Information Quality & 0.824 & 0.723 & 0.895 & 0.726 & 0.897 \\
\hline System Quality<-->Service Quality & 0.756 & 0.653 & 0.844 & 0.655 & 0.846 \\
\hline Information Quality<-->Service Quality & 0.820 & 0.720 & 0.888 & 0.732 & 0.896 \\
\hline
\end{tabular}

\section{Structural Relations Analysis}

\section{Goodness-of-fit Analysis Of The Research Model}

Based on the research of $\mathrm{Wu}$ (2009) and Bentler (1995), this study assesses overall model fit using the seven indices of absolute fit, incremental fit, and parsimonious fit measures: $\chi 2$ test, $\chi 2$ to degrees of freedom ratio, as well as a goodness of fit index (GFI), adjusted goodness of fit index (AGFI), root mean square error of approximation (RMSEA), comparative fit index (CFI), and parsimony-adjusted comparative fit index (PCFI). As shown in Table 6, the results of fitness analysis for the model of this study. Overall, the indices all conform to standard values, indicating that the model of this study is acceptable.

Table 6: Fitness Analysis of Research Model

\begin{tabular}{|c|c|c|c|c|}
\hline Fit Indices & Allowable Standard & $\begin{array}{c}\text { Model (Before } \\
\text { Modification) }\end{array}$ & $\begin{array}{c}\text { Model (After } \\
\text { Modification) }\end{array}$ & $\begin{array}{c}\text { Determination of } \\
\text { Model Fitness }\end{array}$ \\
\hline$\chi^{2}$ & The smaller the better & 1040.357 & 556.018 & \\
\hline$\chi^{2}$ df & $<3$ & 2.307 & 1.951 & Fit \\
\hline GFI & $>0.8$ & 0.806 & 0.867 & Fit \\
\hline AGFI & $>0.8$ & 0.772 & 0.836 & Fit \\
\hline RMSEA & $<0.08$ & 0.072 & 0.062 & Fit \\
\hline CFI & $>0.9$ & 0.949 & 0.971 & Fit \\
\hline PCFI & $>0.5$ & 0.863 & 0.851 & Fit \\
\hline
\end{tabular}

2. Test For Research Hypothesis

As shown in Figure 2, the path values of H1, H2, H3, H4, H7, H8, H9, H10, and H11 are 0.30, 0.58, 0.19, $0.18,0.36,0.50,0.44,0.40$, and 0.39 , respectively, all reaching level of significance $(\mathrm{p}<0.05)$. 


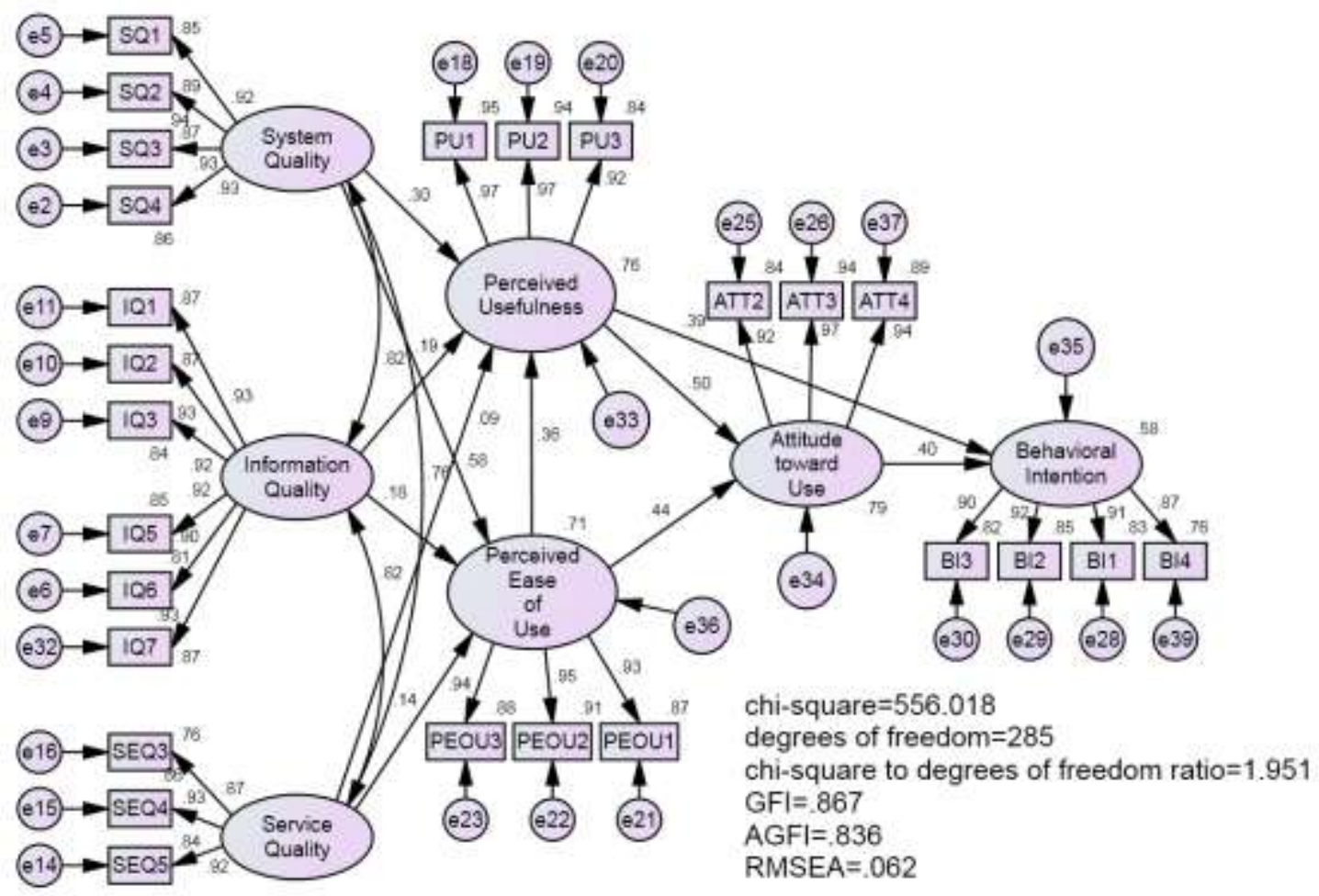

Figure 2: Path Diagram for the Research Model

As shown in Table 7, System quality has a significant positive impact on user's perceived usefulness, supporting Hypothesis 1. System quality has a significant positive impact on user's perceived ease of use, supporting Hypothesis 2. Information quality has a significant positive impact on user's perceived usefulness, supporting Hypothesis 3. Information quality has a significant positive impact on user's perceived ease of use, supporting Hypothesis 4. Service quality does not have a significant positive impact on user's perceived usefulness, failing to support Hypothesis 5. Service quality does not have a significant positive impact on user's perceived ease of use, failing to support Hypothesis 6. User's perceived ease of use has a significant positive impact on user's perceived usefulness, supporting Hypothesis 7. User's perceived usefulness has a significant positive impact on user's attitude toward using, supporting Hypothesis 8. User's perceived ease of use has a significant positive impact on user's attitude toward using, supporting Hypothesis 9. User's attitude toward using has a significant positive impact on user's behavioral intention to use, supporting Hypothesis 10. User's perceived usefulness has a significant positive impact on user's behavioral intention to use, supporting Hypothesis 11.

Table 7: Empirical Results of the Research Hypotheses

\begin{tabular}{|c|c|c|c|}
\hline Hypothesis & Path Relationship & $\begin{array}{c}\text { Path } \\
\text { Value }\end{array}$ & $\begin{array}{l}\text { Support of } \\
\text { Hypothesis }\end{array}$ \\
\hline 1 & System quality to perceived usefulness & $0.30 *$ & Yes \\
\hline 2 & System quality to perceived ease of use & $0.58^{*}$ & Yes \\
\hline 3 & Information quality to perceived usefulness & $0.19 *$ & Yes \\
\hline 4 & Information quality to perceived ease of use & $0.18^{*}$ & Yes \\
\hline 5 & Service quality to perceived usefulness & 0.09 & No \\
\hline 6 & Service quality to perceived ease of use & 0.14 & No \\
\hline 7 & Perceived ease of use to perceived usefulness & $0.36 *$ & Yes \\
\hline 8 & Perceived usefulness to attitude toward using & $0.50 *$ & Yes \\
\hline 9 & Perceived ease of use to attitude toward using & $0.44^{*}$ & Yes \\
\hline 10 & Attitude toward using to behavioral intention to use & $0.40^{*}$ & Yes \\
\hline 11 & Perceived usefulness to behavioral intention to use & $0.39 *$ & Yes \\
\hline
\end{tabular}




\section{3. $\quad$ Test Of Mediation Effects}

As shown in Table 8, the total effect of perceived ease of use on attitude toward using is 0.862 , standard error (S.E.) is 0.053 , and C.R value is 16.264 . The lower limit of percentile $95 \%$ CI is 0.755 and the upper limit is 0.959 . The lower limit of bias-corrected $95 \% \mathrm{CI}$ is 0.758 and the upper limit is 0.961 . C.R value is 16.264 , which is larger than 1.96, thus the total effect is supported. The indirect effect of perceived ease of use on attitude toward using is 0.427 , standard error (S.E.) is 0.085 , and C.R value is 5.024. The lower limit of percentile $95 \%$ CI is 0.283 and the upper limit is 0.591 . The lower limit of bias-corrected $95 \% \mathrm{CI}$ is 0.286 and the upper limit is 0.601. C.R value is 5.024, which is larger than 1.96, thus the indirect effects are supported. The direct effect of perceived ease of use on attitude toward using is 0.435 , standard error (S.E.) is 0.076 , and C.R value is 5.724. The lower limit of percentile $95 \% \mathrm{CI}$ is 0.260 and the upper limit is 0.604 . The lower limit of bias-corrected $95 \% \mathrm{CI}$ is 0.254 and the upper limit is 0.601 . C.R value is 5.724 , which is larger than 1.96 , thus the direct effects are supported. Therefore, perceived ease of use in this study has partial mediation effect on attitude toward using.

Table 8: Analysis of Mediation Effects of Perceived Ease of Use on Attitude toward Using

\begin{tabular}{|c|c|c|c|c|c|c|c|}
\hline \multirow{3}{*}{ Variables } & \multirow{3}{*}{$\begin{array}{c}\text { Point } \\
\text { Estimation }\end{array}$} & \multirow{2}{*}{\multicolumn{2}{|c|}{ Product of Coefficients }} & \multicolumn{4}{|c|}{ Bootstrapping } \\
\hline & & & & \multicolumn{2}{|c|}{ Bias-corrected 95\% CI } & \multicolumn{2}{|c|}{ Percentile $95 \%$ CI } \\
\hline & & SE & $\mathbf{Z}$ & Lower & Upper & Lower & Upper \\
\hline \multicolumn{8}{|l|}{ Total effect } \\
\hline $\begin{array}{l}\text { Perceived Ease } \\
\text { of Use on } \\
\text { Attitude toward } \\
\text { Using }\end{array}$ & .862 & .053 & 16.264 & .758 & .961 & .755 & .959 \\
\hline \multicolumn{8}{|l|}{ Indirect effects } \\
\hline $\begin{array}{l}\text { Perceived Ease } \\
\text { of Use on } \\
\text { Attitude toward } \\
\text { Using }\end{array}$ & .427 & .085 & 5.024 & .286 & .601 & .283 & .591 \\
\hline \multicolumn{8}{|l|}{ Direct effects } \\
\hline $\begin{array}{l}\text { Perceived Ease } \\
\text { of Use on } \\
\text { Attitude toward } \\
\text { Using }\end{array}$ & .435 & .076 & 5.724 & .254 & .601 & .260 & .604 \\
\hline
\end{tabular}

\section{DISCUSSION AND SUGGESTIONS}

\section{Discussion}

This study adopts TAM and uses system quality, information quality, and service quality in the ISSM as external variables to investigate attitude toward using and behavioral intention to use RFID door security system. The results of this study are as follows:

\section{The Impact Of System Quality On Perceived Usefulness And Perceived Ease Of Use}

The empirical results of this study show that system quality has a significant positive impact on perceived usefulness and perceived ease of use. It infers that since the RFID door security system controls the access for entering and exiting Taipei Arena Ice Land, its users consider it important whether the RFID door security system functions correctly and efficiently so as to grant unencumbered entry into the skating rink. The results of this study support research results from the past. That is, system quality has a significant positive impact on perceived usefulness and perceived ease of use (Shen, 2007; Hua, 2007).

\section{2. $\quad$ The Impact Of Information Quality On Perceived Usefulness And Perceived Ease Of Use}

The results of this study show that information quality has a significant positive impact on perceived usefulness and perceived ease of use. It is inferred that because the RFID system stores and manages individual information for the purpose of identification, the completeness and diversity of the information are related to user 
perception of ease of use or functionality. Therefore, information quality has a significant positive impact on perceived usefulness and perceived ease of use. These results match the results of Wei and Lai (2011).

\section{The Impact Of Service Quality On Perceived Usefulness And Perceived Ease Of Use}

The empirical results of this study show that service quality does not have a significant positive impact on perceived usefulness and perceived ease of use. It is inferred that for users of RFID door security systems, service quality has relatively less impact in the environment of the RFID door security system; in other words, the service quality of Ice Land personnel has less impact on user perceptions of the RFID door security system. On the other hand, users may pay more attention to system stability and precision of identification to guarantee unencumbered entry and exit. Such results match the research results of Xie (2007) and Wei and Lai (2011).

\section{4. $\quad$ The Impact Of Perceived Ease Of Use On Perceived Usefulness}

The empirical results of this study show that perceived ease of use has a significant positive impact on perceived usefulness. Such results match the research results of Davis, Bagozzi and Warshaw(1989). It is inferred that when users of the RFID door security system perceive that the RFID interface is easy to operate, they will conclude that the RFID system is useful. This is because, through simple operation, they can pass through the door security system smoothly and enter the skating rink.

\section{The Impact Of Perceived Usefulness And Perceived Ease Of Use On Attitude Toward Using}

The empirical results of this study show that perceived usefulness and perceived ease of use have a significant positive impact on attitude toward using. It is inferred that, as users can experience the ease of use and functionality of the RFID door security system, which in turn grants convenient entry and exit, it will generate a positive response in them. Such results match the research results of Sanchez-Franco (2010) and Lu, Zhou, \& Wang (2009).

\section{6. $\quad$ The Impact Of Attitude Toward Using On Behavioral Intention To Use}

The empirical results of this study show that attitude toward using has a significant positive impact on behavioral intention to use. Such results match the research results of Picazo-Vela, Chou, Melcher \& Pearson (2010) and Ness, Brennan, Oughton, Ritson, and Ruto (2010). It is inferred that users perceive that RFID is a convenient and useful door security system which grants convenient and smooth passage in and out of Ice Land. Therefore, they are willing to continue using it and recommend it to friends.

\section{The Impact Of Perceived Usefulness On Behavioral Intention To Use}

The empirical results of this study show that perceived usefulness has a significant positive impact on the behavioral intention to use. Such results match the research results of Bhattacherjee (2001). It is inferred that the RFID door security system makes the Taipei Arena more accessible to customers, thereby gaining more recognition for the functionality and practicality of the system so that their intention to use the system increases greatly.

\section{The Impact Of Perceived Ease Of Use On Attitude Toward Using Through Perceived Usefulness}

The empirical results of this study show that perceived ease of use has a significant positive impact on attitude toward using through perceived usefulness. As RFID door security system users perceive its ease of use, they will connect its usefulness with product functionality; therefore, user satisfaction will be reflected in attitude toward the product. 


\section{Suggestions}

\section{Practical Suggestions}

The results of this study confirm that system quality has a positive impact on both perceived usefulness and perceived ease of use. This indicates that users at Taipei Arena Ice Land hold positive views toward system quality of its RFID door security system. Therefore, it is recommended that Taipei Arena Ice Land continue its regular maintenance work in order to guarantee the proper functioning of the RFID door security system and ensure its functionality so that users of Ice Land can pass through the RFID door security system in the simplest and most efficient way. Moreover, the results of the study also confirm that perceived ease of use has a positive impact on perceived usefulness which indicates that consumers at Taipei Arena Ice Land have perceived that RFID door security system is easy to use and operate. Therefore, it is recommended that Taipei Arena Ice Land improve on the convenience and sensory sensitivity of the EasyCard to promote ease of use in order to boost consumer recognition of and intention to use RFID door security systems.

\section{Suggestions For Future Studies}

\section{$\underline{\text { Research Object }}$}

This study only considers the consumers at Taipei Arena Ice Land. Therefore, the results are inevitably limited. Focusing on other sport stadiums with RFID door security systems in the future may allow for wider range of research objects and higher degrees of inference.

\section{$\underline{\text { Research Variable }}$}

This study uses system quality, information quality, and service quality in ISSM and perceived ease of use and perceived usefulness in TAM to examine consumer intention to use the RFID door security system at Taipei Arena Ice Land. However, other factors that influence consumer intention to use RFID remain to be examined. Conducting qualitative research, such as in-depth interview, as extensions of research variable or aspect in the future may complement research completeness.

\section{$\underline{\text { Research Methodology }}$}

This study uses questionnaires and may be limited in presenting a comprehensive representation of consumers' intention to use the RFID door security system. Therefore, it is suggested that future studies conduct more in-depth interviews with Ice Land consumers and carry out more thorough on-sight observations in order to understand consumers' views toward the research topic. This will help researchers to interpret consumer intention to use the RFID door security system and promote research value.

\section{Field Of Research}

While the model of this study passes the fitness test, the model is only applied to the study of Taipei Arena Ice Land consumers. Future studies are encouraged to focus on RFID door security systems in venues with different characteristics, such as museums, hospitals, and hotels, in order to further test the feasibility of this model and expand research results.

\section{AUTHOR INFORMATION}

Dr. Kuei-Mei Cheng received the M. A. degree in health, physical education and recreation from University of South Dakota, USA in 1997 and the DSM degree in sport management from United States Sports Academy, USA, in 2004. In 2004, she joined the faculty of National Taiwan University of Physical Education \& Sport as an associate professor in the department of sports management. Her areas of research interest are consumer behavior, service quality, and marketing strategy. E-mail: ccmei@ntupes.edu.tw; kmaycheng@yahoo.com.tw 


\section{REFERENCES}

1. Ahn, T., Ryu, S., \& Han, I. (2007). The impact of web quality and playfulness on user acceptance of online retailing. Information \& Management, 44(3), 263-275.

2. Bentler, P. M. (1995). EQS: Structural equations program manual. Encino, CA: Multivariate Software.

3. Cai, Y. J., \& Liang, J. M. A (2009). Study of using information system success model and technology acceptance model to explore health information system for elementary school. Kaohsiung Normal University Journal, 27, 35-59.

4. $\quad$ Chen, Z. Z., Shi, F. M., Cai, M. R., and Zhou, W. Y. (2009). The past, present, and future of RFID. Sinotech Engineering, 102, 7-13.

5. Chen, J. W. (2010). Investigating the intention of e-portfolio usage combining information system success model with technology acceptance model. Unpublished master's thesis, National Taichung University of Science and Technology, Taichung City.

6. Cheong, J. H., \& Park, M. C. (2005). Mobile internet acceptance in Korea. Internet Research, 15(2), $125-140$

7. Cox, J. (2007). RFID gets new life. Network World, 24(45), 14-16.

8. Davis, F. D. (1986). A technology acceptance model of empirically testing new end-user information systems: theory and results. Unpublished doctoral dissertation. Sloan School of Management, Massachusetts Institute of Technology.

9. Davis, F. D. (1989). Perceived usefulness, perceived ease of use, and user acceptance of information technology. MIS Quarterly, 13(3), 319-340.

10. Davis, F. D., Bagozzi, R. P. and Warshaw, P. R. (1989). User acceptance of computer technology: a comparison of two theoretical models. Management Science, 35(8), 982-1003.

11. DeLone, W. H. \& McLean E. R. (1992).Information systems success: the quest for the dependent variable. Information Systems Research, 3(1), 60-95.

12. DeLone, W. H., \& McLean. E. R (2003). The DeLone and McLean model of information systems success: A ten-year update. Journal of Management Information Systems, 19(4), 9-30.

13. DeLone, W. H. McLean, E. R. (2004). Measuring commerce success: applying the DeLone \& McLean information systems success model, International Journal of Electronic Commerce, 9(1), 31-47.

14. Hua, Y. D. (2007). Using TAM to explore children's moodle learning behavior-taking an issue of computing education as example. Unpublished master's thesis. Tunghai University, Taichung City.

15. Li, M. N. (2006). An introduction to Amos and its uses in scale development: graphics \& basic. Taipei: Psychological Publishing.

16. Li, Z. M. (2009). RFID industry in Taiwan and strategy in initiating RFID Applications in Public Sectors. Paper presented at the 2009 RFID Commerce Integration and Application Conference.

17. Liao, B. Y. (2007). The research of the radio frequency identification to apply to supply chain management-regard wholesaler as the example, Unpublished master's thesis, Chinese Culture University, Taipei City.

18. Lin J. C. C. and Lu. H. (2000). Towards an understanding of the behavioral intention to use a web site. International Journal of Information Management, 20(3), 197-208.

19. Lin, J. L. (2007). Investigating consumers' intention to use mobile value-added services: an integrated framework of TAM and D \& M information systems success model. Unpublished master's thesis, Ming Chuan University, Taipei City.

20. Lin, J. W. (2011). A study of e-service technology at National Tai-Chung Library Based on technology readiness and technology acceptance model. Unpublished master's thesis, National Taiwan University, Taipei City.

21. Liu, G. W. (2008). An exploratory study of the library information system at National Ping-Tung University of Education based on the technology acceptance model and information system success model. Unpublished master's thesis, National Pingtung University of Education, Pingtung City.

22. Lu, Y., Zhou, T. and Wang, B. (2009). Exploring Chinese users' acceptance of instant messaging using the theory of planned behavior, the technology acceptance model, and the flow theory. Computers in Human Behavior, 25(1), 29-39. 
23. Ness, M. R., Ness, M., Brennan, M., Oughton, E., Ritson, C., Ruto, E. (2010). Modeling consumer behavioral intentions towards food with implications for marketing quality low-input and organic food. Food Quality and Preference, 21(1), 100-111.

24. Oztaysi, B., Baysan, S., \& Akpinar, F. (2009). Radio frequency identification (RFID) in hospitality. Technovation, 29(9), 618-624.

25. Picazo-Vela, S., Chou, S. Y., Melcher, A. J., Pearson, J. M. (2010). Why provide an online review? An extended theory of planned behavior and the role of Big-Five personality traits. Computers in Human Behavior, 26(4), 685-696.

26. Saeed, K. A., Hwang, Y. and Yi, M. Y. (2003). Toward an integrative framework for online consumer behavior research: A meta-analysis approach. Journal of End User Computing, 15(4), 1-26.

27. Sanchez-Franco, M. J. (2010). WebCT: the Quasimodo rating effect of perceived affective quality on an extending technology acceptance model. Computers and Education, 54(1), 37-46.

28. Shen, X. F. (2007). Using technology acceptance model to explore e-learning of learning satisfaction and purchase intentions. Unpublished master's thesis, National Dong Hwa University, Hualien County.

29. Shen, Z. S. A (2008). Context-aware application for supermarket shopping guide and product recommendations. Unpublished master's thesis, Chinese Culture University, Taipei City.

30. Song, C. Z., Tang, H. R., Wang, P. J., and Chen, Y. K. (2009). System design and construction of a networking information platform for RFID systems. Hwa Kang Journal of Engineering, 24, 149-158.

31. Torkzadeh, G., Koufteros, X., \& Pflughoeft, K. (2003). Confirmatory analysis of 35 computer self-efficacy. Structural Equation Modeling, 10(2), 263-275.

32. Wang, S. H. (2008). The influence of innovation characteristics to nurse staff intention in using RFID: Comparison with one-layer model and multi-layer model. Journal of Management Practices and Principles, 2(4), 87-106.

33. Wang, S. H. (2007). Nursing staff perception of efficacy of RFID and behavioral intention to employ RFID technology. The Journal of Health Science, 9(2), 89-102.

34. Weng, R. M. (2008). The functional analysis of computer assisted instruction platform based on TAM and IS success model. Unpublished master's thesis, Department Management Information Systems, National Pingtung University of Science and Technology, Pingtung County.

35. Wei, W.Q. \& Lai, J. L. (2011).An empirical study of the critical factors influencing users' intentions on online beauty store. International Journal of LISREL, 4(2), 70-94.

36. Wu, M. L. (2009). Structural equation modeling method and practical application. Kaohsiung: Liwen Publisher.

37. Xu, W. H. (2005). The user intention of web-based advanced traveler information system: a case study of freeway real-time traffic information website in Taiwan. Unpublished master's thesis, National Cheng Kung University, Tainan City.

38. Xie, Y. J. (2007). How the existence of physical channel affects the customers' decision in the multi-channel environment. Unpublished master's thesis, Department of Information Management, National Central University, Taoyuan County.

39. Yang, Z. X. (2005). Comparison and evaluation between RFID and bar code tech efficiency - hypermarket's accounting as an example. Unpublished master's thesis, Kun Shan University, Tainan City

40. Zhou, S. J. (2006). A study on the masses' acceptance of RFID system applied in medical clinics. Unpublished master's thesis, Tamkang University, New Taipei City.

41. Zhang, J. B. (2011). Application of campus facility management system using RFID and GIS techniques. Unpublished master's thesis, Chien Hsin University of Science and Technology, Taoyuan County. 


\section{NOTES}

